\title{
Stress, Spirituality and Altruism of Brazilian Medical Students during the Covid-19 Pandemic: A Cross- sectional Analysis
}

\section{David Nunes de Lima Jr ( $\sim$ davidn@alu.ufc.br)}

Federal University of Ceará https://orcid.org/0000-0003-0382-5924

Ridson Guilherme Parente de Aguiar

Christus University Center

\section{Bruna Sobreira Kubrusly}

Federal University of Ceará

Danielle S. Macedo

Federal University of Ceará

Marcos Kubrusly

Christus University Center

Danilo Lopes Ferreira Lima

University of Fortaleza, Christus University Center

\section{Lia Lira Olivier Sanders}

Federal University of Ceará and Christus University Center

\section{Research Article}

Keywords: Psychological stress, Coping strategies, Altruistic attitudes, Spirituality, Covid-19 pandemic

Posted Date: September 23rd, 2020

DOI: https://doi.org/10.21203/rs.3.rs-66418/v1

License: (c) (1) This work is licensed under a Creative Commons Attribution 4.0 International License. Read Full License

Version of Record: A version of this preprint was published at Research, Society and Development on September 23rd, 2020. See the published version at https://doi.org/10.33448/rsd-v11i7.29513. 


\section{Abstract}

When psychosocial stress overcomes people's coping capacity, spirituality and altruism may become necessary to minimize psychological damage. This study analyzed self-reported measures of stress, spirituality and altruism of 1105 Brazilian Medical students during the Covid-19 pandemic. We found moderate levels of perceived stress, moderate to high levels spirituality, as well as high levels of altruistic attitudes. Reported stress was higher among participants with a previous diagnosis of mental disorder and women. Spirituality correlated positively with altruistic thoughts and emotions, but only altruism was inversely related to stress. Future research should explore the role of spirituality and altruism in stress management.

\section{Introduction}

Outbreaks of infection have the potential to profoundly impact people at the individual, community, and international levels (Hall et al., 2008). On an individual level, people are likely to experience fear of falling sick or dying and be concerned about their future and their family's health, which causes different levels of stress and other psychological effects (Wang et al., 2020).

The 2019 coronavirus disease (Covid-19) pandemic is a public health emergency of international concern. The increasing numbers of cases all over the world required a series of dramatic containment measures (Lancet, 2020). Millions of lives have been significantly altered, so that we are now experiencing an ongoing global, stress-coping-adjustment process.

Many countries have asked people to isolate themselves at home. A recent review of the psychological impact of quarantine identified a series of stressors, such as longer quarantine duration, infection fears, frustration, boredom, inadequate supplies, inadequate information, financial loss, and even stigma (Brooks et al., 2020).

When psychosocial stress overcomes people's coping capacity, protective factors, such as spirituality and altruism, become necessary to minimize psychological damage. Spirituality tends to shape social behaviors (Zerbetto et al., 2017) and may serve as a buffer for the potential deleterious effects of disasters (Aten et al., 2014). According to Pan-American Health Organization, the experience acquired in epidemics demonstrates that the attention to mental health cannot be limited to specialized services. It also requires humanitarian and social help, which is intrinsically related to altruism (Organização PanAmericana da Saúde (OPAS/OMS), 2006).

In the common sense, altruism is usually seen as generosity and beneficence. Psychology defines it as acting out of concern for the welfare of others (Fehr \& Fischbacher, 2003). Spirituality is a subjective experience difficult to describe. It involves values and beliefs of community that may provide a sense of fulfillment in life (Bensley, 1991). Jung suggested that the spiritual belief in some unifying force may 
strength personal growth (Jung, 1969). Spirituality and altruism may be important coping strategies to minimize the insecurity, the pain and the conflicts at crisis moments.

Here we analyzed self-reported measures of stress, spirituality and altruism of 1105 Brazilian Medical students during the Covid-19 pandemic. Although there is an intuition that spirituality and altruism are related, we wanted to investigate how they each other and whether they participants' level of stress in critical periods. We hypothesized that participants with higher levels spirituality and altruism would report a lower level of stress. We were also interested in understanding how previous mental health status and social isolation would influence participants' level of stress during the Covid-19 pandemic.

\section{Methods}

\section{Participants and Study Design}

This study was conducted during the last week of March and the first week of April, when most Brazilian states had already been promoting social isolation in response to the Covid-19 pandemic for two weeks and the infection rate was rising steeply. We used social media groups of Brazilian medical schools to recruit participants. Medical students were invited to answer an online questionnaire. They provided information about biological sex, age, marital status, number of residents in their home, medical school, state of the federation, city location (capital or countryside), year in medical school (medical school in Brazil is a six-year program). We asked if they or any family member were a suspected or confirmed case of Covid-19 and if they were in total or partial social isolation. We also asked whether they were currently involved in patients' care, how many weekly hours they have been dedicating to academic studying during the pandemic, and whether they had been monitored for the treatment of any mental disorder before the begin of the pandemic.

\section{Instruments}

After the questions described above, participants answered three self-reported measures: the Perceived Stress Scale 4 (PSS-4) (Cohen \& Williamson, 1988), the Self-Spirituality Rating Scale (SRSS) (Galanter et al., 2007), and Altruistic Attitudes Scale (Escala de Atitudes Altruístas) (Loureiro, 2009). The PSS-4 is a four-item scale about the frequency of stress symptoms. Participants respond on a 5-point Likert-type scale $(0=$ never; $4=$ very often). The scale focuses on general aspects, rather than on specific experiences and has been validated for Brazilian Portuguese (Faro, 2015). To evaluate the acute effects of social isolation, we changed the question about the frequency of symptoms "in the last month" to "in the last week". After answering the PSS-4, participants were asked if stress symptoms have started or intensified with the Covid-19 pandemic or the social isolation. The Self-Spirituality Rating Scale (SRSS) has also been validated for Brazilian Portuguese (De Souza Gonçalves \& Pillon, 2009). It is composed of six questions about how participants care about and engage in spiritual practices. Participants indicate their answers to each of the six items on a 5-point Likert scale (from 1-I totally agree to 5-I totally disagree). Prior to computing the sum, each item is recoded (i.e., the score of 5 becomes $1 ; 2$ becomes 4 ; and so forth). The sum of the responses to the six items indicates the total score for spiritual orientation 
(between 6 and 30). The Altruistic Attitudes Scale (Escala de Atitudes Altruístas) was developed in Portuguese and validated in Portugal (Loureiro, 2009). It consists of 12 items that evaluate cognitive, affective and behavioral aspects of altruism.

\section{Statistical Analysis}

We used the Statistical Package for the Social Sciences (SPSS), version 23, for the statistical analysis, considering $p<0.05$ as a significant value. The data were not normally distributed. Therefore, descriptive statistics were reported as median (Mdn) and interquartile range (IQR). We used the chi-square test for assessing relationships between categorical variables, as well as the Mann-Whitney test and the KruskalWallis where appropriate. For correlation analysis, we used Spearman's rank correlation.

\section{Ethical Considerations}

All procedures performed in studies involving human participants were in accordance with the ethical standards from Brazil, following resolution No. 510 of April 2016 for conducting in the humanities and social sciences, with the standards of free and informed consent and with the 1964 Helsinki declaration and its later amendments or comparable ethical standards. As a COVID-19 related research protocol, this project has been be reviewed and approved by the National Commission of Ethics in Research - CONEP (protocol number: 4014340). Informed consent was obtained from all individual adult participants included in the study.

\section{Results}

A total of 1105 Brazilian medical students of all years of medical school took part in the study. Sample characteristics are displayed in Table 1. Most of the participants were female (64.2\%), single (94.8\%), and between 20 to 29 years old (73.3\%). The majority live in capitals or metropolitan regions $(79.6 \%)$, especially in the Northeast Region (72.5\%), in households with more than three people (58.3\%).

Most participants (96\%) were not suspected or confirmed cases of Covid-19 nor had any family member diagnosed with the disease (94.8\%). A $77.9 \%$ majority was totally confined to their homes or leaving home only to obtain essential goods and services. Moreover, $95.3 \%$ of the students were not in direct contact with patients during the pandemic.

We found moderate levels of perceived stress in this population of medical students during the Covid-19 pandemic (figure 1). While most participants (66.5\%) declared that stress symptoms have started or intensified with the Covid-19 pandemic or the measures of social isolation, $14.1 \%$ did not see a relationship between their level of stress and the pandemic, and $19.4 \%$ denied any symptom of stress.

We asked participants whether they had been receiving mental health treatment before the begin of the pandemic. This was the case for $21.8 \%$ of participants, whose level of stress was significantly higher compared to participants without a previous diagnosis of mental disorder $(p<0.001)$ (table 2$)$. Women had a higher level of perceived stress $(p<0.001)$ (table 2$)$ and there was a negative correlation between 
the number of hours of study per week ( $M d n=10, I Q R=5-24)$ and the level of stress $(\rho=-0.173 ; p<$ $0.001)$.

The level of stress was not higher among participants living in the four Brazilian states with highest incidence states of Covid-19 (table 2) as compared those of other states, which suggests that stress does not depend on the local stage of the pandemic. The level of stress did not differ depending on whether or not the participants (Mdn =9, IQR $=5-11 \mathrm{vs}$. $M d n=8, I Q R=6-10$; Mann-Whitney, $p=0.49$ ) or a relative of theirs (Mdn = 9, IQR = 6-11 vs. Mdn = 8, IQR = 6-10; Mann-Whitney, $p=0.21$ ) was a suspected or confirmed case of Covid-19. The perceived stress of participants who were in total or partial social isolation also did not differ from those that were not $(\mathrm{Mdn}=8$, IQR = 5-11 vs. $M d n=8, I Q R=5-10$; MannWhitney, $p=0.43$ ). We found the same for students who were in direct contact with patients during the pandemic. Their level of stress did not differ from that of students who were not ( $M d n=9, I Q R=5-10$ vs. $\mathrm{Mdn}=8, \mathrm{IQR}=6-11, \mathrm{p}=0.64$ ). Age, marital status, number of people living in their home, region of Brazil, city location, and year of medical school did not influence students' level of stress $(p>0.05)$.

Participants had a moderate to high level of spirituality and a high level of altruistic attitudes (figure 1). The level of spirituality was significantly different among the regions of the country $(p<0.001$, table 2$)$. Participants from the Northeast and Midwest of Brazil reported higher levels of spirituality than those from the South and Southeast of Brazil. The spirituality of participants from the North of Brazil did not differ from the other groups of regions.

Women reported higher levels of spirituality and altruism than men $(p<0.001$, table 2$)$. Participant aged 20 years and older showed higher levels of altruism than participants younger than 20 years $(p<0.001$, table 2). Marital status, number of people in the home, living in a capital or in the countryside, year of medical school had no relationship with the levels of spirituality and altruism (table 2). Interestingly, selfreported spirituality was slightly higher among participants from the four states that have been hardest hit by the virus (table 2).

We found a significant correlation between spirituality and altruism $(\rho=0.14, p<0.001)$, especially the cognitive and affective dimensions of altruism $(p<0.001)$, indicating that participants with higher spirituality report more altruistic thoughts and feelings. Moreover, there was a significant negative correlation between level of stress (PSS-4) and altruism $(\rho=-0.07, p=0.025)$, particularly the behavioral dimension of altruism $(p=0.048)$.

\section{Discussion}

The Covid-19 pandemic is putting enormous stress on all of us. In this study, we analyzed self-reported measures of stress, spirituality and altruism of 1105 Brazilian Medical students during the Covid-19 pandemic. We found moderate levels of perceived stress, moderate to high levels of spirituality, as well as high levels of altruistic attitudes. Participants with a previous diagnosis of mental disorder and women reported higher levels of stress during the Covid-19 pandemic. There was a significant negative 
correlation between level of stress and altruism, as well as a significant correlation between spirituality and altruism.

Being in social isolation or living in a state with high incidence of Covid-19 did not seem to influence the level of stress at least at the early stage of the pandemic. The level of stress was the same irrespective of being in direct contact with patients during the pandemic or being a suspected or confirmed case of Covid-19. Moreover, the level of stress was also the same in the five regions of Brazil. Taken together, these results suggest that the stress related to the pandemic is a more general preoccupation than a local phenomenon. The only regional difference was in spirituality, which was strongest in the Northeast and Midwest of Brazil. Previous research has identified an association between religiosity and poverty (Schweiger, 2019). In our study, participants' level of spirituality was indeed lower in the South and Southeast region, which are the two richest Brazilian macro-regions.

Our results indicate that the mental health status before the Covid-19 pandemic influences the current level of stress, which was higher in the group of people who were already being monitored at a mental health service. People suffering from a mental illness seem to have more difficult to cope with the stress during the Covid-19 pandemic. There is evidence linking mental disorders with persistent hypercortisolemia, which may lead to stronger emotional responses to life events (Goh \& Agius, 2010). Moreover, females had a higher level of stress when compared to males. Most epidemiological studies have demonstrated that women suffer more anxiety and depression than men (Kessler et al., 1994) (Wittchen et al., 1992) and that stress is more strongly related to psychiatric symptoms in women (Sandanger et al., 2004). A possible explanation for the greater stress vulnerability of females is that the rise of testosterone in males during adolescence may blunt their responsiveness to stress (Becker et al., 2007).

A recently published Chinese study showed that female gender, student status and poor self-rated health status were associated with a greater psychological impact of the outbreak of Covid-19 and higher levels of stress, anxiety, and depression (Wang et al., 2020). In our study, we found moderate levels of stress among Brazilian medical students during the pandemic. There was an inverse relationship between students' hours of study and the level of stress, indicating a possible scenario of functional impact of stress during the Covid-19 pandemic. Previous research has shown that working engagement is negatively correlated with perceived stress in medical students (Agarwal et al., 2020). It is possible that studying may have contributed to reduce the level of perceived stress of some students amidst the Covid19 pandemic.

We found high levels of self-reported altruistic attitudes (total sum) in medical students. The literature on altruistic attitudes of medical students is scarce. A qualitative study with nine medical students from the United Kingdom revealed that they do not consider altruism as essential to the role of a doctor. Nevertheless, participants express a preference to work with or be an altruistic doctor (Marynissen \& Spurrier, 2018). Another study found that altruistic behaviors are rather infrequent among medical 
students, even though younger students tend to be more altruists (Sanjai \& Gopichandran, 2018). In our study, the level of altruism was not influenced by year of medical school.

Among the diverse perspectives for understanding the altruistic attitude, Rosenberg and Hovland separate three components of altruism (Rosenberg et al., 1960). The cognitive component corresponds to what people think of altruistic attitude; the affective component, to how they feel about altruism; the behavioral component, to their commitment to altruistic behavior. Looking at the cognitive, affective and behavioral aspects of the Altruistic Attitudes Scale, we found that spirituality correlated positively with the cognitive and affective subscales, while stress correlated negatively with the behavioral subscale. This suggests that spirituality and cognitive and affective aspects of altruism may have more in common than we know, but only altruistic behavior is inversely related to stress.

It is generally assumed that people who lead a more spiritual life tend to develop more generous, less selfish attitudes and look more to their neighbor. Renowned authors such as Freud and Skinner postulated a positive relationship between religiosity/spirituality and altruism, however it has never been clear whether the values acquired in the practice of faith can be translated into altruistic behaviors (Saroglou, 2012). Huber and MacDonald investigated the relationship between altruism, empathy and spirituality in university students. They found a direct positive relationship between spiritual experiences and altruism as well as indirect positive effect of spiritual cognitions on altruism through empathy (Huber \& MacDonald, 2012) . Here we observed a positive correlation between spirituality and altruism, in agreement with classic psychology theories. Spirituality correlated positively with altruistic thoughts and emotions, but not with altruistic behavior, which suggests a more cognitive impact of spirituality on altruism, that not necessarily leads to altruistic behavior.

In the present study, women reported more spirituality than men. This result parallels findings of studies showing that women consistently score higher than men on measures of spirituality and religious involvement (Dillon et al., 2003)(Maselko \& Kubzansky, 2006). The strong spirituality among women can be related to charitable involvement, equanimity, and religious skepticism (Bryant, 2007). Although there are not many studies analyzing the level of spirituality of medical students, there is some evidence that spiritual, religious, and existential concerns are relevant to students as they search for meaning and purpose in their lives and develop effective stress-coping mechanisms (Avila, 2010)(Krägeloh et al., 2015).

\section{Limitations}

This study is a cross-sectional study with limitations that deserve mention. Although we asked about participants' mental health before the Covid-19 pandemic, we have no parameters to compare their previous level of stress, altruism and spirituality with the current level. It is therefore not possible to establish a causal relationship between the pandemic and the stress experienced by study participants. The correlations that we found between altruism and stress, and between spirituality and altruism are significant, but weak, indicating that their relationship explain only a small part of the investigated factors. Moreover, we used self-reported measures, which means that the levels of stress, spirituality and 
altruism reported are subjective measures that depend on participants' level of insight and do not necessarily correspond to their feelings and daily behavior.

\section{Conclusion}

Our results identified moderate levels of perceived stress, moderate to high levels of spirituality, and high levels of altruistic attitudes. There were no regional differences in the level of stress, which did not depend on the local incidence of Covid-19 nor on participants social isolation at that stage of the pandemic. Participants with a previous diagnosis of mental disorder and women were more vulnerable to stress during the Covid-19 pandemic. In accordance with previous theories, we found a significant correlation between spirituality and altruism, especially between spirituality and altruistic thoughts and feelings. The inverse relationship between altruistic attitudes and stress deserves further investigation, as altruism may turn out to be an important stress coping strategy.

\section{Declarations}

Funding No funding was received for this study

\section{Compliance with Ethical Standards}

Conflict of Interest The authors declare they have no conflicts of interest.

\section{References}

1. Agarwal, G., Mosquera, M., Ring, M., \& Victorson, D. (2020). Work engagement in medical students: An exploratory analysis of the relationship between engagement, burnout, perceived stress, lifestyle factors, and medical student attitudes. Medical Teacher, 42(3), 299-305. https://doi.org/10.1080/0142159X.2019.1679746

2. Aten, J. D., O’Grady, K. A., Milstein, G., Boan, D., \& Schruba, A. (2014). Spiritually oriented disaster psychology. Spirituality in Clinical Practice, 1(1), 20-28. https://doi.org/10.1037/scp0000008

3. Avila, L. (2010). Avaliação da espiritualidade e religiosidade dos estudantes de medicina e implicações frente a sua formação médica. Arquivo de Ciencias Da Saúde, v. 17.

4. Becker, J. B., Monteggia, L. M., Perrot-Sinal, T. S., Romeo, R. D., Taylor, J. R., Yehuda, R., \& Bale, T. L. (2007). Stress and disease: Is being female a predisposing factor? Journal of Neuroscience, 27(44), 11851-11855. https://doi.org/10.1523/JNEUROSCI.3565-07.2007

5. Bensley, R. J. (1991). Defining Spiritual Health: A Review of the Literature. Journal of Health Education, 22(5), 287-290. https://doi.org/10.1080/10556699.1991.10614636

6. Brooks, S. K., Webster, R. K., Smith, L. E., Woodland, L., Wessely, S., Greenberg, N., \& Rubin, G. J. (2020). The psychological impact of quarantine and how to reduce it: rapid review of the evidence. Lancet (London, England), 395(10227), 912-920. https://doi.org/10.1016/S0140-6736(20)30460-8 
7. Bryant, A. N. (2007). Gender differences in spiritual development during the college years. Sex Roles, 56(11-12), 835-846. https://doi.org/10.1007/s11199-007-9240-2

8. Cohen, S., \& Williamson, G. (1988). Perceived stress in a probability sample of the United States. In: Spacapan S and Oskamp S (eds). The Social Psychology of Health., 31-68.

9. De Souza Gonçalves, A. M., \& Pillon, S. C. (2009). Adaptação transcultural e avaliação da consistência interna da versão em português da Spirituality Self Rating Scale (SSRS). Revista de Psiquiatria Clinica, 36(1), 10-15. https://doi.org/10.1590/s0101-60832009000100002

10. Dillon, M., Wink, P., \& Fay, K. (2003). Is Spirituality Detrimental to Generativity? Journal for the Scientific Study of Religion, 42(3), 427-442. https://doi.org/10.1111/1468-5906.00192

11. Faro, A. (2015). Confirmatory factor analysis of three versions of the perceived stress scale (PSS): A population-based study. Psicologia: Reflexao e Critica, 28(1), 21-30. https://doi.org/10.1590/16787153.201528103

12. Fehr, E., \& Fischbacher, U. (2003). The nature of human altruism. Nature, 425(6960), 785-791. https://doi.org/10.1038/nature02043

13. Galanter, M., Dermatis, H., Bunt, G., Williams, C., Trujillo, M., \& Steinke, P. (2007). Assessment of spirituality and its relevance to addiction treatment. Journal of Substance Abuse Treatment, 33(3), 257-264. https://doi.org/10.1016/j.jsat.2006.06.014

14. Goh, C., \& Agius, M. (2010). The stress-vulnerability model how does stress impact on mental illness at the level of the brain and what are the consequences? Psychiatria Danubina, 22(2), 198-202.

15. Hall, R. C. W., Hall, R. C. W., \& Chapman, M. J. (2008). The 1995 Kikwit Ebola outbreak: lessons hospitals and physicians can apply to future viral epidemics. General Hospital Psychiatry, 30(5), 446-452. https://doi.org/10.1016/j.genhosppsych.2008.05.003

16. Huber, J. T., \& MacDonald, D. A. (2012). An investigation of the relations between altruism, empathy, and spirituality. Journal of Humanistic Psychology, 52(2), 206-221.

https://doi.org/10.1177/0022167811399442

17. Jung, C. G. (1969). Psychology and religion: West and east (2nd ed.). The collected works of C. G. Jung, Vol.11.

18. Kessler, R. C., McGonagle, K. A., Zhao, S., Nelson, C. B., Hughes, M., Eshleman, S., Wittchen, H. U., \& Kendler, K. S. (1994). Lifetime and 12-month prevalence of DSM-III-R psychiatric disorders in the United States. Results from the National Comorbidity Survey. Archives of General Psychiatry, 51(1), 8-19. https://doi.org/10.1001/archpsyc.1994.03950010008002

19. Krägeloh, C. U., Henning, M. A., Billington, R., \& Hawken, S. J. (2015). The relationship between quality of life and spirituality, religiousness, and personal beliefs of medical students. Academic Psychiatry: The Journal of the American Association of Directors of Psychiatric Residency Training and the Association for Academic Psychiatry, 39(1), 85-89. https://doi.org/10.1007/s40596-014-0158-z

20. Lancet, T. (2020). COVID-19: learning from experience. In Lancet (London, England) (Vol. 395, Issue 10229, p. 1011). https://doi.org/10.1016/S0140-6736(20)30686-3

21. Loureiro, A. (2009). Escala de atitudes altruistas: Estudo de validaçào e fíabilidade. 7(1), 73-83. 
22. Marynissen, K., \& Spurrier, B. (2018). Becoming the "good doctor": medical students' views on altruism and professional identity. MedEdPublish, 7(1), 1-14.

https://doi.org/10.15694/mep.2018.0000052.1

23. Maselko, J., \& Kubzansky, L. D. (2006). Gender differences in religious practices, spiritual experiences and health: results from the US General Social Survey. Social Science \& Medicine (1982), 62(11), 2848-2860. https://doi.org/10.1016/j.socscimed.2005.11.008

24. Organização Pan-Americana da Saúde (OPAS/OMS). (2006). Proteção Da Saúde Mental Em Situações De Epidemias. https://www.paho.org/hq/dmdocuments/2009/Protecao-da-SaudeMentalem-Situaciones-de-Epidemias-Portugues.pdf

25. Rosenberg, M. J., Hovland, C. I., McGuire, W. J., Abelson, R. P., \& Brehm, J. W. (1960). Attitude organization and change: An analysis of consistency among attitude components. (Yales studies in attitude and communication.), Vol. III. In Attitude organization and change: An analysis of consistency among attitude components. (Yales studies in attitude and communication.), Vol. III. Yale Univer. Press.

26. Sandanger, I., Nygård, J. F., Sørensen, T., \& Moum, T. (2004). Is women's mental health more susceptible than men's to the influence of surrounding stress? Social Psychiatry and Psychiatric Epidemiology, 39(3), 177-184. https://doi.org/10.1007/s00127-004-0728-6

27. Sanjai, S., \& Gopichandran, V. (2018). Selfless giving in medicine: a study of altruistic attitudes among medical students. Indian Journal of Medical Ethics, 3(1), 28-34. https://doi.org/10.20529/IJME.2017.082

28. Saroglou, V. (2012). Religion, spirituality, and altruism. APA Handbook of Psychology, Religion, and Spirituality (Vol 1): Context, Theory, and Research., 1, 439-457. https://doi.org/10.1037/14045-024

29. Schweiger, G. (2019). Religion and poverty. Palgrave Communications, 5(1), 59. https://doi.org/10.1057/s41599-019-0272-3

30. Wang, C., Pan, R., Wan, X., Tan, Y., Xu, L., Ho, C. S., \& Ho, R. C. (2020). Immediate psychological responses and associated factors during the initial stage of the 2019 coronavirus disease (COVID19) epidemic among the general population in China. International Journal of Environmental Research and Public Health, 17(5). https://doi.org/10.3390/ijerph17051729

31. Wittchen, H. U., Essau, C. A., von Zerssen, D., Krieg, J. C., \& Zaudig, M. (1992). Lifetime and six-month prevalence of mental disorders in the Munich Follow-Up Study. European Archives of Psychiatry and Clinical Neuroscience, 241(4), 247-258. https://doi.org/10.1007/bf02190261

32. Zerbetto, S. R., Gonçalves, A. M. de S., Santile, N., Galera, S. A. F., Acorinte, A. C., \& Giovannetti, G. (2017). Religiosity and spirituality: mechanisms of positive influence on the life and treatment of alcoholics. Escola Anna Nery - Revista de Enfermagem, 21(1), 1-8. https://doi.org/10.5935/14148145.20170005

\section{Tables}

Table 1 Sample Characteristics 


\begin{tabular}{|c|c|c|c|}
\hline Variable & & $\mathbf{n}$ & $\%$ \\
\hline \multirow[t]{2}{*}{ Sex } & Feminine & 709 & 64.2 \\
\hline & Masculine & 396 & 35.8 \\
\hline \multirow[t]{3}{*}{ Age Range } & $<20$ & 233 & 21.1 \\
\hline & 20 to 29 & 810 & 73.3 \\
\hline & $>30$ & 62 & 5.6 \\
\hline \multirow[t]{3}{*}{ Marital Status } & Single & 1047 & 94.8 \\
\hline & Married & 56 & 5.1 \\
\hline & Divorced & 2 & 0.2 \\
\hline \multirow[t]{2}{*}{ Number of People in the Home } & $<5$ & 461 & 41.7 \\
\hline & $\geq 5$ & 644 & 58.3 \\
\hline \multirow[t]{5}{*}{ Region of Brazil } & Northeast & 801 & 72.5 \\
\hline & Southeast & 121 & 11.0 \\
\hline & Midwest & 113 & 10.2 \\
\hline & South & 50 & 4.5 \\
\hline & North & 20 & 1.8 \\
\hline \multirow[t]{2}{*}{ City Location } & Capital/Metropolitan region & 880 & 79.6 \\
\hline & Countryside & 225 & 20.4 \\
\hline \multirow[t]{7}{*}{ Year of Medical School } & 1 & 273 & 24.7 \\
\hline & 2 & 232 & 21.0 \\
\hline & 3 & 223 & 20.2 \\
\hline & 4 & 180 & 16.3 \\
\hline & 5 & 104 & 9.4 \\
\hline & 6 & 93 & 8.4 \\
\hline & Total & 1105 & 100.0 \\
\hline
\end{tabular}

Table 2 Association between Variables and Scale 


\begin{tabular}{|c|c|c|c|c|}
\hline Variable & & $\begin{array}{l}\text { Perceived } \\
\text { Stress } \\
\text { Scale } 4 \\
\text { (PSS-4) }\end{array}$ & $\begin{array}{l}\text { Self- } \\
\text { Spirituality } \\
\text { Rating Scale } \\
\text { (SRSS) }\end{array}$ & $\begin{array}{l}\text { Altruistic } \\
\text { Attitudes } \\
\text { Scale (Total } \\
\text { score) }\end{array}$ \\
\hline \multirow[t]{3}{*}{ Sex } & \multirow{3}{*}{$\begin{array}{l}\text { Feminine } \\
\text { Masculine }\end{array}$} & $9(7-11)$ & \multirow{2}{*}{$\begin{array}{l}21(16- \\
25), p< \\
0.001^{1}\end{array}$} & \multirow{2}{*}{$\begin{array}{l}53(49-56) \\
p<0.0011\end{array}$} \\
\hline & & \multirow{2}{*}{$7(5-10)$} & & \\
\hline & & & $18(14-23)$ & $52(47-55)$ \\
\hline \multirow[t]{4}{*}{ Age Range } & $<20$ & \multirow{2}{*}{$\begin{array}{l}8(6-11) \\
, p=0.683^{2}\end{array}$} & \multirow{2}{*}{$\begin{array}{l}19(15-24) \\
p=0.420^{2}\end{array}$} & \multirow{2}{*}{$\begin{array}{l}51(47-54) \\
a, p<0.001^{2}\end{array}$} \\
\hline & \multirow{2}{*}{$20-29$} & & & \\
\hline & & $8(6-10)$ & $20(15-24)$ & $53(49-56) b$ \\
\hline & $>30$ & $8(5-10)$ & $21(17-25)$ & $53(51-56) b$ \\
\hline \multirow[t]{4}{*}{ Marital Status } & \multirow{2}{*}{$\begin{array}{l}\text { Single } \\
\text { Married }\end{array}$} & $8(6-11)$ & \multirow{2}{*}{$\begin{array}{l}20(15- \\
24), p= \\
0.090^{2}\end{array}$} & $\begin{array}{l}52(48-55) \\
p=0.290^{2}\end{array}$ \\
\hline & & \multirow{2}{*}{$8(6-10)$} & & \multirow{3}{*}{$\begin{array}{l}53(50,5-56) \\
53(51-55)\end{array}$} \\
\hline & \multirow[t]{2}{*}{ Divorced } & & \multirow{2}{*}{$\begin{array}{l}21(18-25) \\
16.5(15- \\
18)\end{array}$} & \\
\hline & & $8.5(6-11)$ & & \\
\hline \multirow[t]{2}{*}{$\begin{array}{l}\text { Number of People in the } \\
\text { Home }\end{array}$} & \multirow{2}{*}{$\begin{array}{l}<5 \\
\geq 5\end{array}$} & $\begin{array}{l}8(6-10), p \\
=0.745^{1}\end{array}$ & $\begin{array}{l}20(16-24) \\
p=0.0971\end{array}$ & \multirow{2}{*}{$\begin{array}{l}52(49-56) \\
p=0.273^{1} \\
52(48-55)\end{array}$} \\
\hline & & $8(6-11)$ & $20(16-24)$ & \\
\hline \multirow[t]{7}{*}{ Region of Brazil } & \multirow{2}{*}{$\begin{array}{l}\text { Northeast } \\
\text { Southeast }\end{array}$} & $\begin{array}{l}9(6-11), p \\
=0.339^{2}\end{array}$ & \multirow{2}{*}{$\begin{array}{l}20(16.5- \\
24) a, p< \\
0.001^{2}\end{array}$} & $\begin{array}{l}52(49-55) \\
p=0.244^{2}\end{array}$ \\
\hline & & $8(6-10)$ & & \multirow{2}{*}{$52(48-55)$} \\
\hline & \multirow{2}{*}{ South } & & $21(16-25)$ & \\
\hline & & $\begin{array}{l}9.5(0.5- \\
11.5)\end{array}$ & & $\begin{array}{l}51(45.5- \\
52,5)\end{array}$ \\
\hline & North & $8(5-10)$ & 22) ab & $53(51-56)$ \\
\hline & & $9(6-10)$ & $\begin{array}{l}15(12-22) \\
b\end{array}$ & $53(49-56)$ \\
\hline & & & $\begin{array}{l}17(11-22) \\
b\end{array}$ & \\
\hline $\begin{array}{l}\text { Participants from the } 4 \\
\text { states with highest incidence }\end{array}$ & Yes & $\begin{array}{l}8(6-10), p \\
=0.239^{1}\end{array}$ & $\begin{array}{l}20(15-25)) \\
\mathbf{p}=0.0091\end{array}$ & $\begin{array}{l}52(48-55) \\
p=0.176^{1}\end{array}$ \\
\hline I covide & INO & $9(6-11)$ & $\begin{array}{l}19.5(14- \\
23)\end{array}$ & $53(49-56)$ \\
\hline City location & $\begin{array}{l}\text { Capital/Metropolitan } \\
\text { Region }\end{array}$ & $\begin{array}{l}8(6-10), p \\
=0.1541\end{array}$ & $\begin{array}{l}20(15-24) \\
p=0.773^{1}\end{array}$ & $\begin{array}{l}52(48-55) \\
p=0.286^{1}\end{array}$ \\
\hline & Countryside & $9(6-11)$ & $21(16-24)$ & $53(49-56)$ \\
\hline
\end{tabular}




\begin{tabular}{|lclll|} 
Year of Medical School & $1-2$ & $\begin{array}{l}8(6-11), \mathrm{p} \\
=0.999^{2}\end{array}$ & $\begin{array}{l}20(15-24), \\
\mathrm{p}=0.780^{2}\end{array}$ & $\begin{array}{l}52(48-55), \\
\mathrm{p}=0.160^{2}\end{array}$ \\
& $3-4$ & $8(6-10)$ & $20(15-25)$ & $53(49-56)$ \\
& $5-6$ & $8(6-11)$ & $20(16-24)$ & $53(49-56)$ \\
\hline $\begin{array}{l}\text { Previous Diagnose of Mental } \\
\text { Disorder }\end{array}$ & Yes & $\begin{array}{l}10(7-12), \\
\mathbf{p}<0.001^{1}\end{array}$ & $\begin{array}{l}16(12-23), \\
\mathrm{p}=0.185^{1}\end{array}$ & $\begin{array}{l}52(49-55), \\
\mathrm{p}=0.264^{1}\end{array}$ \\
& No & $8(5-10)$ & $16(12-21)$ & $53(48-56)$ \\
\hline
\end{tabular}

Values indicated as Median (Interquartile range), level of significance. Letters a,b indicate the result of multiple comparison test. Values identified by the same letter $(a, b)$ indicate that the medians were not significantly different indicate same medians. If two letters are listed $(a, b)$, the median was not significantly different from medians identified by either a or b. 1 Mann-Whitney Test; ${ }^{2}$ Kruskal-Wallis Test.

Table 3 Correlations between Stress, Spirituality and Altruism

\begin{tabular}{|lll|}
\hline Scale & $\begin{array}{l}\text { Perceived Stress Scale 4 } \\
\text { (PSS-4) }\end{array}$ & $\begin{array}{l}\text { Self-Spirituality Rating Scale } \\
\text { (SRSS) }\end{array}$ \\
\hline $\begin{array}{l}\text { Self-Spirituality Rating Scale } \\
\text { (SRSS) }\end{array}$ & $\rho=0.03, p=0.255$ & - \\
\hline $\begin{array}{l}\text { Altruistic Attitudes Scale (total } \\
\text { score) }\end{array}$ & $\rho=-0.07, \mathbf{p}=\mathbf{0 . 0 2 5}$ & $\rho=0.14, \mathbf{p}<0.001$ \\
\hline Cognitive subscale & $\rho=-0.05, p=0.106$ & $\rho=0.13, \mathbf{p}<0.001$ \\
\hline Affective subscale & $\rho=-0.05, p=0.095$ & $\rho=0.16, \mathbf{p}<0.001$ \\
\hline Behavioral subscale & $\rho=-0.06, \mathbf{p}=0.048$ & $\rho=0.05, p=0.107$ \\
\hline
\end{tabular}

Spearman's rank correlation coefficient (Spearman's $\rho$ ), significance level.

\section{Figures}



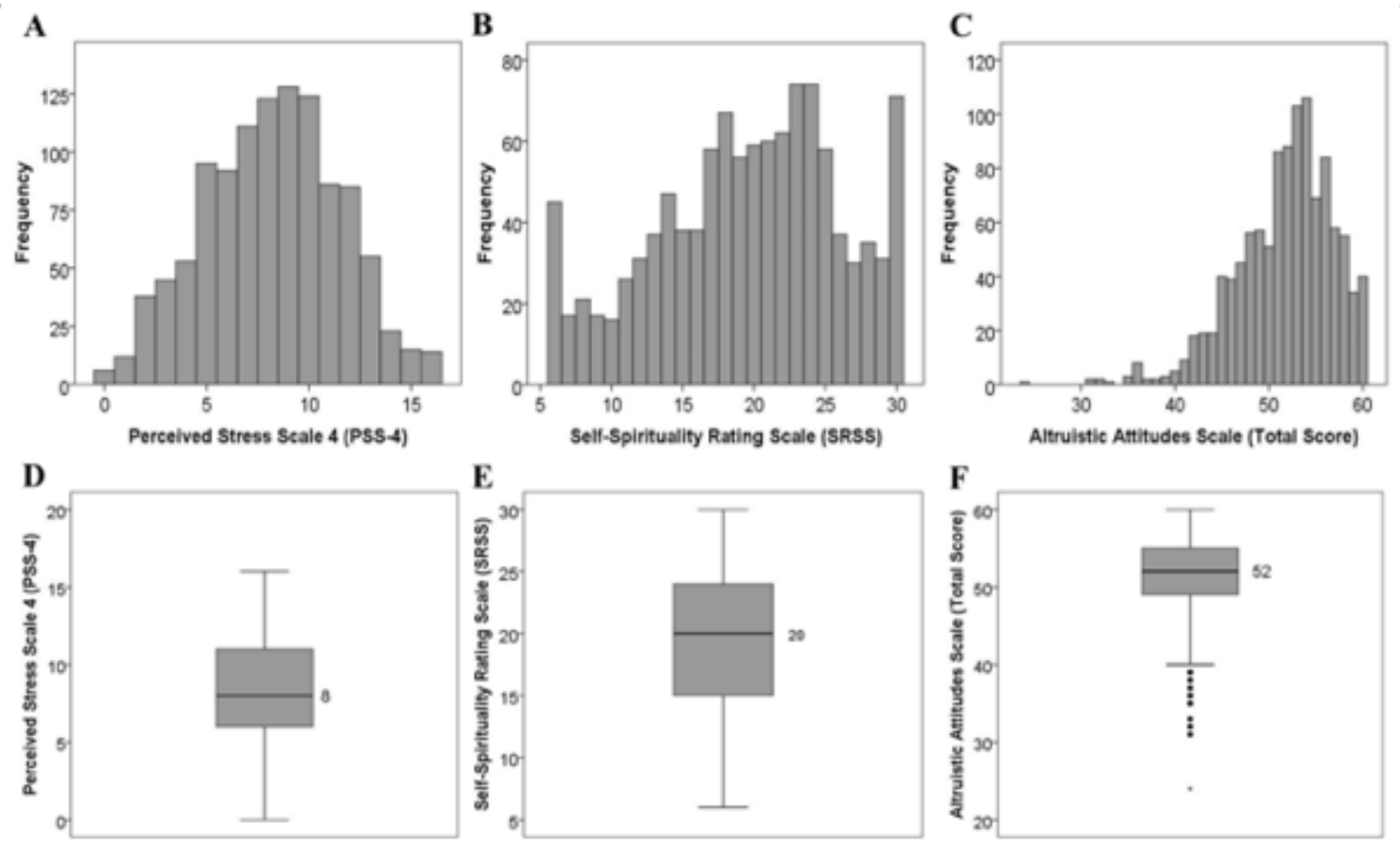

\section{Figure 1}

Participants' Level of Stress, Spirituality and Altruism. Histograms showing the distribution of scores on each scale: Perceived Stress Scale 4 (A), Self-Spirituality Rating Scale (B) and Altruistic Attitudes Scale (C); the box plots in the bottom (D, E, F) indicate the respective medians. 